\title{
MENELISIK HUKUM JUAL BELI KREDIT MELALUI KAJIAN TAFSIR AL-QURAN
}

\author{
Khozainul Ulum \\ Universitas Islam Lamongan \\ e-mail: averroz@gmail.com
}

\begin{abstract}
In fulfilling the needs, human beings tend to do various ways and always looking for ease. In the context of the fulfillment of economic needs, for example, not everyone can get easy access to be able to get the needs. The purchasing power of each person always refers to the stability of the amount of income earned every day or every month. Therefore, it is not surprising that payment system in transaction of buying and selling that try to make easy for consumer to get what is wanted, that is credit payment. In Islam, payments in credit transactions are known as nasiah. This paper will trace the arguments of the Quran that are related to the payment of sale and purchase on credit. From the Quranic interpretation of sura al-Baqarah verse 282 and 283 above with respect to the transaction on credit, it can be summarized as follows. First, the transaction on credit in Islam is not forbidden and not makruh. In other words, it is allowed even though the price of goods sold in credit is more expensive than the price in cash. Second, in a transaction on credit, it is ordered to make record and witness to the requierments and conditions of the transaction. The purpose of these records and testimony is to safeguard the rights of each transactor and to avoid disputes in the future. In this case, ulama have difference on the form of such recording and testimonies. One side believes that the order is obligatory (wajib), and the other side thinks it sunnah. According to me, after seeing the purpose of record and testimony of the above transactions, the record and testimony in the transaction is wajib.Third, transaction made in cash (yadan bi yadin), according to the author, is also required to record and testimony. This is a form of caution, because at the moment there are many disputes in transactions that arise in the community, even though they have done the recording and testimony. Fourth, note of treaty and the receipts included in each transaction at the present have an important meaning to safeguard the rights and obligations of each party conducting the transaction. Moreover, note of treaty and receipt are a valid and concrete evidence explaining the truth of the transaction.
\end{abstract}

Keywords: credit sale, Quranic interpertation approach

\section{Pendahuluan}

Sudah menjadi kodrat manusia sebagai makhluk sosial yang meniscayakan adanya hubungan timbal balik, baik hubungan tersebut memiliki ikatan yang didasarkan pada akad maupun hanya berdasarkan suka rela. Hubungan mutualis simbiosis ini selalu menyertai kehidupan manusia, tidak hanya pada ranah kecil seperti keluarga, namun juga pada ranah yang lebih luas yaitu manusia sebagai konstruks masyarakat.

Konsekuensi logis dari manusia sebagai konstruks masyarakat adalah bahwa mereka memiliki keterkaitan dan keterikatan satu sama lain, bahwa mereka membutuhkan satu sama 
lain dalam setiap aspek, baik itu politik, ekonomi, sosial, budaya dan lain sebagainya. Setiap orang pasti memiliki kekurangan dan itu hanya bisa disempurnakan oleh eksistensi orang lain.

Dalam bidang ekonomi - seperti dalam jual beli - misalnya, tidak semua orang bisa mendapatkan akses mudah untuk mampu mendapatkan kebutuhan. Daya beli setiap orang selalu merujuk kepada stabilitas jumlah penghasilan yang didapat setiap hari atau setiap bulannya. Karena itu, tidak mengherankan jika kemudian muncul sistem pembayaran dalam akad (transaksi) jual beli yang mencoba memberikan kemudahan bagi konsumen untuk mendapatkan apa yang diinginkan, yaitu melalui pembayaran kredit.

Dewasa ini, sistem pembayaran kredit menjadi opsi sekaligus kecenderungan bagi sebagian konsumen dalam setiap melakukan transaksi jual beli, meskipun dari pihak produsen atau agen juga menyertakan penawaran sistem pembayaran secara tunai. Semisal dalam transaksi pembelian sepeda motor atau mobil, sistem kredit dalam perbankan, bahkan dalam transaksi yang paling sederhana sekalipun, seperti transaksi pembelian alat-alat rumah tangga.

Dalam tulisan ini, penulis mencoba mencari dan menelusuri dalil-dalil al-Quran yang menjelaskan tentang sistem kredit. Apakah al-Quran, yang merupakan sumber aturan bagi umat Islam, berbicara tentang sistem kredit mengingat sebagian masyarakat Islam juga memiliki kecenderungan terhadap sistem kredit ini dalam berbagai transaksi jual beli.

\section{Definisi dan Jenis-Jenis Kredit}

Istilah kredit dalam bahasa Arab dikenal dengan al-bay' bi thaman ājil (nasiah). Dalam Ensiklopedi Hukum Islam, term kredit didefinisikan dengan akad atau transaksi jual beli dengan cara berutang. ${ }^{1}$ Artinya, penjual menyerahkan barang yang dijualnya kepada pembeli dengan harga yang disepakati bersama, tetapi pembayarannya tidak secara tunai melainkan ditangguhkan sampai pada jangka waktu yang ditentukan. Terkadang penjual menerima sebagian harganya secara tunai sedangkan sisanya dibayar secara mengangsur. Terkadang pula penjual tidak menerima sedikitpun uang muka, melainkan seluruh harganya dibayar secara kredit.

Ada dua macam bentuk jual beli kredit yang terjaadi dalam sistem jual beli, yaitu : ${ }^{2}$

1. Jual beli kredit dimana barang yang dijual secara kredit memiliki kesamaan harga jika dijual dengan sistem pembayaran tunai. Artinya, barang yang diperjualbelikan memiliki nilai harga yang sama, baik dijual dengan menggunakan sistem pembayaran kredit maupun tunai.

2. Jual beli kredit dimana barang yang dipejualbelikan secara kredit harganya lebih mahal jika dibandingkan dengan pembayaran secara tunai.

Dilihat dari segi bentuk pembayarannya, ada yang dilakukan sekaligus bila sudah sampai pada waktu yang ditetapkan, dan ada yang dilakukan secara cicilan atau angsuran sesuai dengan waktu dan jumlah pembayaran yang disepakati bersama.

\section{Dalil al-Quran}

Untuk mencari dalil al-Quran yang menjelaskan tentang sistem kredit, pertama kali yang perlu dilakukan adalah menentukan keyword atau kata kunci. Dengan definisi kredit di

\footnotetext{
${ }^{1}$ Abdul Aziz Dahlan [et al], Ensiklopedi Hukum Islam, cet. 5 (Jakarta: Ichtiar Baru van Hoeve, 2001), 978.

${ }^{2}$ Ibid., 978-979.
} 
atas, maka lafadz yang dipakai sebagai kata kunci untuk penelusuran adalah $\quad$ دين dan. Melalui lafadz , dan sebagai kata kunci, penelusuran dilakukan dengan

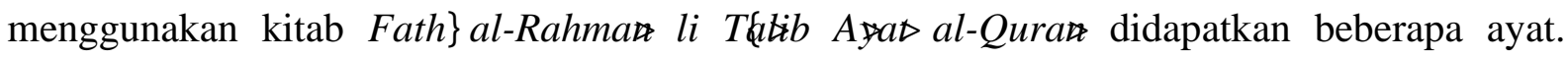
Namun, dari beberapa ayat tersebut, hanya dua ayat dalam Surat al-Baqarah yang menjelaskan dan berkaitan dengan sistem kredit, yaitu al-Quran Surat al-Baqarah ayat 282 dan 283. Berikut ini adalah dua ayat yang dimaksud:

$$
\begin{aligned}
& \text { ا ـ يأيها الذين ءامنوا إذا تداينتم بدين إلى أجل مسمى فاكتبوه وليكتب بينكم كاتب بالعدل ولا يأب كاتب أن } \\
& \text { يكتب كما علّمه الله فليكتب وليملل الذي عليه الحق وليتق الله ربّه ولا يبخس منه شيئا فإن كان الذي عليه }
\end{aligned}
$$

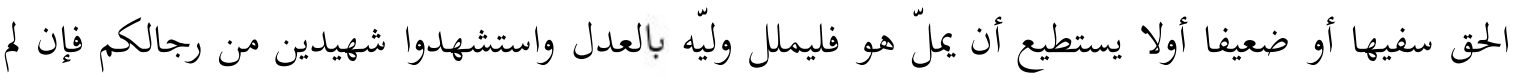

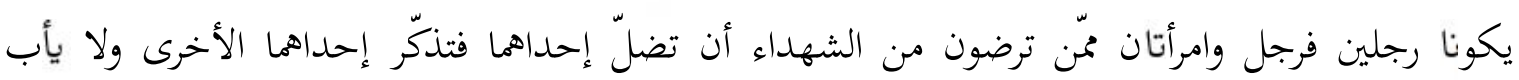

$$
\begin{aligned}
& \text { الشهداء إذا ما دعوا ولا تسئموا أن تكتبوه صغيرا أو كبيرا إلى أجله ذلكم أقسط عند الله وأقوم للشهدة وأدنى } \\
& \text { ألاّ ترنابوا إلاّ أن تكون بترة حاضرة تديروها بينكم فليس عليكم جناح ألاّ تكتبوها وأشهدوا إذا تبايعتم ولا }
\end{aligned}
$$

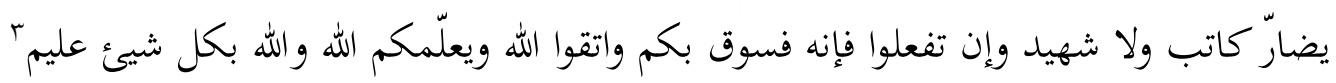

$$
\begin{aligned}
& \text { r. وإن كنتم على سفر ولم بحدوا كاتبا فرهن مقبوضة فإن أمن بعضكم بعضا فليؤدّ الذي اؤتمن أمنته وليتق الله ربّه }
\end{aligned}
$$

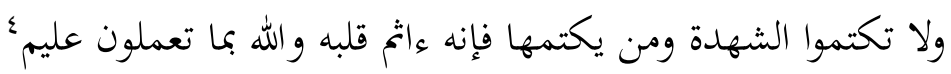

\section{Turunnya Ayat (Nuzubal-A at)}

Langkah selanjutnya adalah menentukan posisi turunnya ayat-ayat tersebut (apakah termasuk makkiy atau madaniy) dan urutan nuzułny. Di sini, pengertian tentang ayat makkiy atau madaniy yang dipakai adalah bahwa ayat makkiy diturunkan sebelum hijrah sedangkan ayat madaniy diturunkan setelah hijrah, terlepas apakah ayat tersebut turun di kota Makkah atau tidak. ${ }^{5}$

Berkaitan dengan posisi turunnya ayat, al-Quran Surat al-Baqarah ayat 282 dan 283 termasuk ayat dalam kategori madaniy. Kesimpulan ini didasarkan pada pertama, hadis Nabi yang diriwayatkan oleh Ibn 'Abbas:

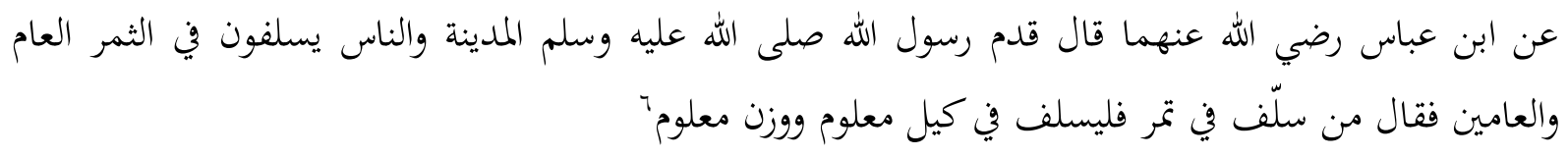

\footnotetext{
3 al-Quran, 2: 282.

4 al-Quran, 2: 283.

5 Pengertian tentang ayat makkiy-madaniy sebenarnya memiliki tiga definisi yang berbeda, namun penulis cenderung memilih pengertian di atas karena cakupannya lebih luas mencakup ayat-ayat yang turun di tengahtengah perjalanan dan yang turun selain di kota Makkah dan Madinah. Lihat Muhammad ibn 'Alawi al-Maliki,

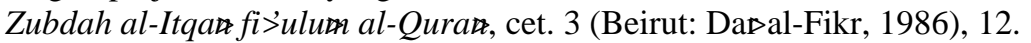

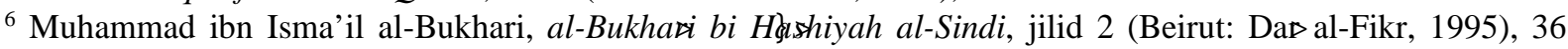
[2239].
} 
Kedua, kelompok surat-surat madaniyyah di mana surat al-Baqarah masuk dalam klasifikasi ini. ${ }^{7}$ Ketiga, ciri-ciri ayat makkiy dan madaniy dimana ciri ayat makkiy didahului dengan kalimat يأيها الناس sedangkan ayat madaniy didahului dengan يأيها الذين أمنوا Keempat, pendapat Ibn Abbas yang mengatakan bahwa ayat di atas turun berkenaan tentang akad salam penduduk Madinah, seperti yang disampaikan oleh al-Qurthubi:

$$
\text { وقيع المداينات إبن عباس : هذه الأية نزلت في السلم خاصة. معناه أن سلم أهل المدينة كان سبب الأية, ثم هي تتناول }
$$

Keterangan senada juga disampaikan oleh Ibn 'Ashur, bahwa al-Quran Surat al-Baqarah ayat 282 dan 283 turun berkenaan dengan akad salam penduduk Madinah:

$$
\text { عن ابن عباس أها نزلت في السلم وكان السلم من معاملات أهل المدينة'” }
$$

Ibn 'Ashur memberikan keterangan tambahan bahwa meskipun kedua ayat tersebut turun berkenaan dengan akad salam penduduk Madinah, namun kekhususan tersebut tidak meniadakan keumuman kedua ayat di atas yang mencakup seluruh bentuk hutang piutang. ${ }^{11}$ Hal ini didasarkan pada kaidah:

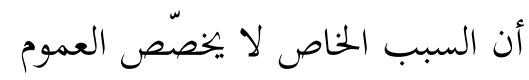

Adapun kedua ayat di atas harus dipahami sesuai dengan urutannya sendiri, karena alQuran Surat al-Baqarah ayat 283 dimulai dengan menggunakan $h \not \jmath r f$ al- 'at j yang masih terkait dengan ayat sebelumnya yaitu al-Quran Surat al-Baqarah ayat 282.

\section{Kesesuaian Ayat (Munasabah al-Ayat)}

Langkah berikutnya adalah mencari munasabah ayat-ayat yang dikaji dengan ayat-ayat sebelum dan sesudahnya. Adapun munasabah dari al-Quran Surat al-Baqarah ayat 282 dan 283 dengan ayat sebelumnya adalah bahwa ayat sebelumnya berbicara tentang riba dan keburukan-keburukan yang disebabkan olehnya, sekaligus menjelaskan haramnya riba. Setelah menjelaskan keharaman riba, kemudian Allah menjelaskan akad hutang piutang yang baik dan diperbolehkan sebagai salah satu cara untuk mengembangkan harta (tanmiyah al$m a A$ yang termaktub dalam al-Quran Surat al-Baqarah ayat 282 dan 283.

Adapun ayat sesudahnya berbicara mengenai kekuasaan Allah untuk memberikan tuntutan (takli^) berupa syariah kepada siapa saja. Syariah yang dimaksud adalah yang

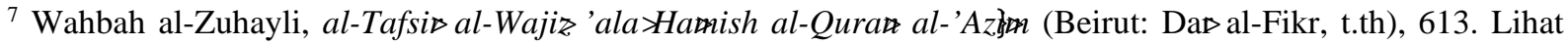
juga Muhammad ibn 'Alawi al-Maliki, Zubdah al-Itqaæ, 13.

${ }^{8}$ Lebih jelasnya lihat Ibid., 12.

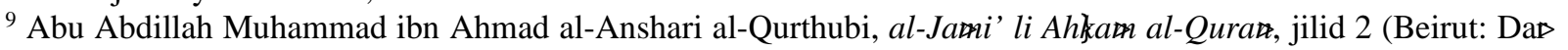
al-Fikr, 1999), 286.

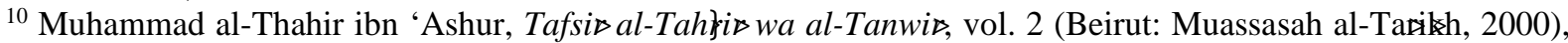
565.

${ }^{11}$ Ibid.
} 
termaktub dalam ayat-ayat sebelumnya yang berbicara tentang shalat, zakat, qisł $\$$ \} $\}$ puasa, haji, jihad, talak, 'iddah, jual beli, hukum riba dan hutang piutang. Ayat sesudahnya juga menjelaskan balasan (pahala) bagi mereka yang melaksanakan syariah Allah.

\section{Tafsi®al-A at}

Dalam al-Quran Surat al-Baqarah ayat 282 terdapat kalimat yang memiliki kesamaan dengan makna kredit dalam Bahasa Arab (al-bay' bi thaman ał⿱亠乂 tadałantum bi daynin ila>ajalin musamma>Kedua kalimat tersebut memberikan pengertian yang sama, yaitu memberikan jangka waktu (tempo) dalam pelunasan akad utang piutang.

Para ulama memberikan penafsiran yang sama terhadap kalimat idha xadałantum bi daynin ila $\gg j a l i n$ musamma $>$ Ibn Kathir menafsirkannya dengan idha $¥ a$ 'a muajjalatin. ${ }^{12}$ Al-Shabuni menafsirkannya dengan idha>ta'a raaltum bi daynin muajjalin. ${ }^{13}$ Penafsiran di atas memiliki pengertian yang sama, yaitu bertransaksi dengan sistem utang piutang dengan pembatasan waktu pembayaran (ajalin musamma).

menurut Ibn 'Ashur adalah menentukan pembatasan waktu pembayaran (jatuh tempo) dengan tujuan untuk menghindari sengketa. ${ }^{14}$ Sedangkan Ibn al-Mundhir mengatakan bahwa firman Allah menunjukkan tidak diperbolehkannya bertransaksi dengan sistem utang piutang (kredit) yang tidak disertai dengan batas waktu pembayaran. ${ }^{15}$ Sehingga merupakan batasan (taqyi $\Varangle$ ) bagi diperbolehkannya bertransaksi dengan sistem utang piutang (kredit). Ketentuan untuk menentukan batas waktu pembayaran dalam transaksi sistem utang piutang senada dengan hadits Nabi:

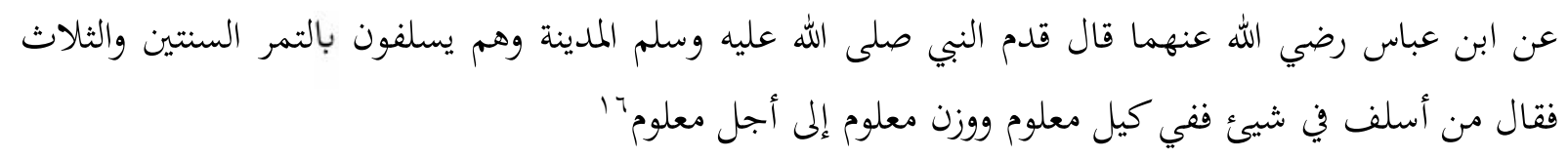

Wahbah menyebutkan bahwa ulama Mazhab Syafi'iy, Hanafi, Maliki, Hambali, Zaid ibn Ali dan jumhur ulama membolehkan jual beli (transaksi) secara kredit (بالتقسيط) dengan harga yang lebih mahal daripada harga transaksi secara tunai. Selanjutnya, ia mengutip keterangan dari Ibn Quddāmah bahwa jual beli secara kredit tidak haram dan juga tidak makruh. Jika pembeli (debitur) sepakat untuk membeli suatu barang secara kredit dengan harga 1.100, padahal harga barang tersebut jika dibeli secara tunai adalah 1.000, maka transaksi seperti ini adalah sah, meskipun pada saat tawar menawar kedua harga tersebut, yaitu harga secara tunai dan secara kredit disebutkan. ${ }^{17}$

merupakan perintah Allah untuk membuat catatan atas terjadinya transaksi dengan sistem utang piutang. Menurut al-Qurthubi, perintah Allah tersebut tidak hanya untuk

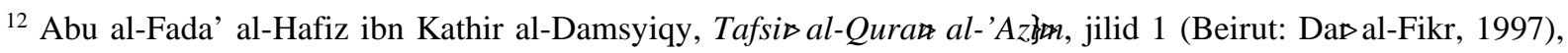
368.

${ }^{13}$ Muhammad Ali al-Shabuni, Słfwah al-Tafasi», jilid 1 (t.tp.: Da®al-Kutub al-Islaæmiyyah, t.th), 177.

${ }^{14}$ Muhammad al-Thahir ibn 'Ashur, Tafsi»al-Tahti» $\gg$ wa al-Tanwi», 565.

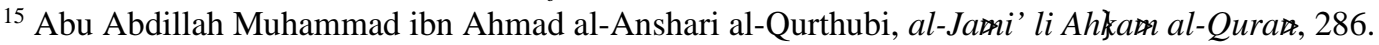

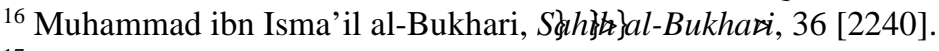

${ }^{17}$ Lebih jelasnya lihat Wahbah al-Zuhayli, al-Fiqh al-Islaær wa Adillatuh, vol. 5, cet. 4 (Beirut: Da〉al-Fikr, 1997), 3461.
} 
membuat catatan melainkan sekaligus perintah untuk membuat kesaksian atas transaksi. ${ }^{18}$ Tujuan dari perintah tersebut, menurut Ibn Kathir, untuk menjaga berlangsungnya transaksi sekaligus sebagai sebuah kepercayan. ${ }^{19}$ Adapun bentuk perintah dari lafaz tersebut diperselisihkan oleh para ulama. Mayoritas ulama berpendapat bahwa perintah pencatatan yang ditunjukkan oleh adalah mandub. Sedangkan al-Thabari mengatakan bahwa bentuk perintah tersebut adalah wajib. ${ }^{20}$

Adapun orang yang bertugas untuk mencatat transaksi dengan sistem utang piutang, menurut Sha'rawi bukanlah para pelaku transaksi (kreditur dan debitur), melainkan orang ketiga yang tidak memiliki kepentingan dalam transaksi tersebut. Pemahaman ini didasarkan

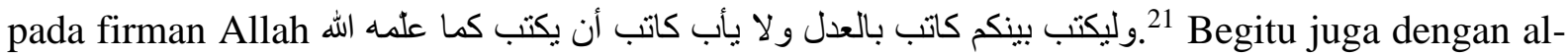
Shabuni yang menafsirkan dengan orang ketiga yang adil, dapat dipercaya dan tidak memiliki kecenderungan kepada salah satu pelaku transaksi. ${ }^{22}$ Karena itu, bagi seseorang yang ahli dalam pencatatan transaksi ketika diminta untuk melakukan pencatatan maka ia tidak boleh menolak ${ }^{23}$ dan wajib mencatatnya dengan jujur. ${ }^{24}$

و لا يأب كاتب أن يكتب . Ibn 'Ashur, berkenaan dengan potongan ayat tersebut mencatat ada beberapa pendapat tentang hukum bagi seseorang yang diminta untuk melakukan pencatatan. Menurut Rabi', Mujahid, 'Atha' dan al-Thabari, berhukum fard $\downarrow$ al-'ain bagi orang yang diminta untuk melakukan pencatatan transaksi. Sedangkan Imam al-Hasan memberikan batasan hukum fardl al-'ain jika di satu daerah hanya ada satu kaðib. Namun, jika di satu

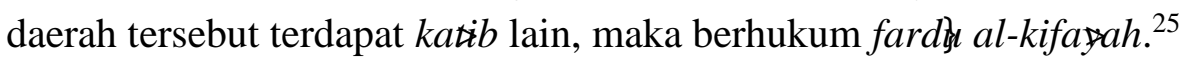

Sedangkan lafaz terdapat beberapa penafsiran. Al-Qurthubi menjadikan lafaz tersebut sebagai sifat dari $\quad{ }^{26}$ Sedangkan Ibn 'Ashur menafsirkan dengan . Ia menolak menjadikan sebagai sifat dari karena adanya hłorf al-jarr. ${ }^{27}$ Senada dengan Ibn 'Ashur adalah penafsiran al-Shabuni yang juga tidak menjadikan sebagai sifat. ${ }^{28}$

ayat ini memerintahkan kepada orang yang berhutang (الذي عليه الحق) atau debitur untuk mendiktekan syarat-syarat dan ketentuanketentuan transaksi dengan sistem utang piutang yang telah disepakati kepada katib tanpa ada penambahan dan pengurangan dari kesepakatan tersebut. ${ }^{29}$ Menurut al-Qurthubi, perintah imla $>$ ditujukan kepada debitur karena kesaksiannya bisa muncul (terjadi) dari pengakuannya (ikrar). ${ }^{30}$

Penafsiran di atas menunjukkan bahwa debitur (الذي عليه الحق) yang diperintahkan untuk mendiktekan syarat-syarat dan ketentuan-ketentuan transaksi yang telah disepakati merupakan orang yang telah memenuhi syarat untuk bermu'amalah, yaitu berakal dan

\footnotetext{
${ }^{18}$ Abu Abdillah Muhammad ibn Ahmad al-Anshari al-Qurthubi, al-Jaæri' li Ahkaæa al-Quraæ, 289.

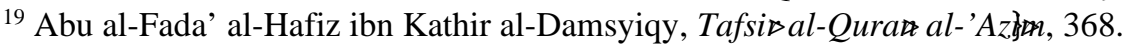

${ }^{20}$ Abu Abdillah Muhammad ibn Ahmad al-Anshari al-Qurthubi, al-Jaæri' li Ahßaær al-Quraæ, 290.

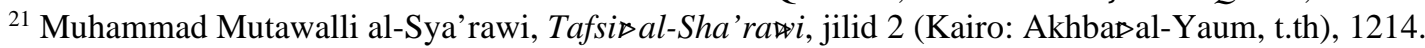

${ }^{22}$ Muhammad Ali al-Shabuni, Słfwah al-Tafasip, 178.

${ }^{23}$ Muhammad Mutawalli al-Sya'rawi, Tafsi $\triangleright a l-S h a ' r a \gg i, 1214$.

${ }^{24}$ Abu Abdillah Muhammad ibn Ahmad al-Anshari al-Qurthubi, al-Jaæi' li Ahka al-Qura®, 291.

${ }^{25}$ Muhammad al-Thahir ibn 'Ashur, Tafsi $>$ al-Tahtipwa al-Tanwiฉ, 567.

${ }^{26}$ Abu Abdillah Muhammad ibn Ahmad al-Anshari al-Qurthubi, al-Jaæii' li Ahkała al-Quraæ, 291.

${ }^{27}$ Muhammad al-Thahir ibn 'Ashur, Tafsi $>$ al-Tahtipwa al-Tanwiฉ, 567.

${ }^{28}$ Muhammad Ali al-Shabuni, Słffwah al-Tafasip, 178.

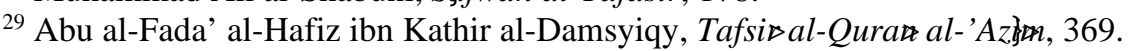

${ }^{30}$ Abu Abdillah Muhammad ibn Ahmad al-Anshari al-Qurthubi, al-Jaæii' li Ahkaær al-Quraæ, 292.
} 
termasuk ahliyah al-tasłırruf. Namun, bagaimana jika debitur adalah orang yang tidak berakal dan bukan ahliyah al-tasłerruf ?. Siapakah yang mendiktekan syarat-syarat dan ketentuanketentuan transaksi yang telah disepakati kepada kasib? Di sini, Allah menjelaskannya dengan فإن كان الذي عليه الحق سفيها أو ضعيفا أو لا يسنطيع أن يملّ هو فلبيملل وليّه بالعدل

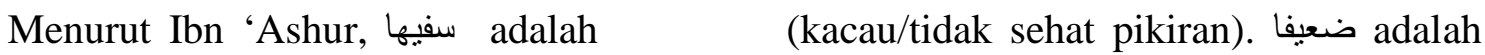
الصغير (anak kecil). لا يسنطيع أن يملّ adalah orang yang lemah ( ), seperti orang bisu, buta dan tuli. ${ }^{31}$ Sedangkan menurut al-Qurthubi, سفيها adalah orang yang bukan termasuk ahliyah

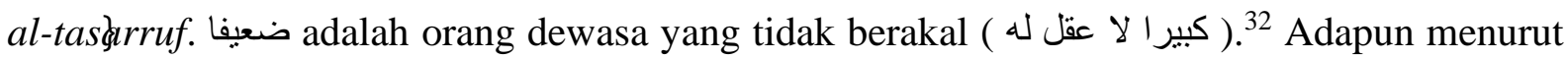

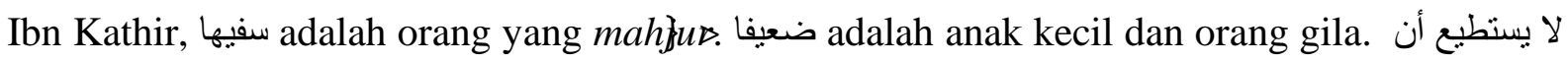
adalah orang yang tidak cakap dan bodoh. ${ }^{33}$

ضenurut potongan ayat di atas, bagi para debitur yang memiliki sifat سفيفا atau لا يستطيع أن يملّ atau , maka yang membacakan atau mendiktekan syarat-syarat dan ketentuanketentuan transaksi kepada kasib adalah para wali mereka. Sedangkan para wali ketika mendiktekan syarat-syarat dan ketentuan-ketentuan transaksi tersebut kepada kąib, wajib menyampaikannya dengan adil dan jujur.

ayat ini merupakan perintah untuk membuat kesaksian dengan dua orang laki-laki dewasa yang Islam. ${ }^{34}$ Menurut Malik, Abu Hanifah dan Syafi'i, yang dikehendaki dari adalah orang laki-laki yang merdeka. Sedangkan menurut Syuraih, Usman al-Batti, Ahmad, Ishaq dan Abu Thaur, sesuai dengan dlahir ayat di atas maka kesaksian budak dapat diterima jika dinilai memiliki sifat adil. ${ }^{35}$

Meskipun membuat pencatatan dalam transaksi kredit diperintahkan, namun, menurut Ibn Kathir membuat pensaksian زالإستشهاد) juga tetap diperintahkan dengan tujuan untuk زيادة)

diperintahkan oleh Allah, para ulama ternyata berbeda pendapat tentang bentuk perintahnya ( $a m r)$, apakah perintah itu berhukum wajib atau sunnah. Menurut mayoritas ulama salaf, bentuk perintah tersebut berhukum wajib. Sedangkan menurut mayoritas ulama fiqh muta'akhkhiritr, bentuk perintah tersebut berhukum sunnah. ${ }^{37}$ Di antara kedua pendapat tersebut, menurut al-Qurthubi yang paling $s\{h$ h yaitu berhukum sunnah. ${ }^{38}$

فإن لم يكونا رجلين فرجل وامرأتان ممّن ترضون من الثهداء أن تضلّ إحداهما فتنكر إحداهما الأخرى Jika dua orang laki-laki di atas tidak dapat ditemukan untuk dijadikan saksi, maka bisa diganti dengan satu orang laki-laki dan dua orang perempuan untuk ditunjuk sebagai saksi. ${ }^{39}$ Menurut mayoritas ulama, penunjukan dua orang perempuan adalah setara dengan satu orang lakilaki, ${ }^{40}$ karena akal perempuan dinilai kurang. ${ }^{41}$ Hal ini kemudian ditegaskan oleh Allah dengan أن تضلّ إحداهما فتذكر إحداهما الأخرى, yaitu karena akal perempuan dinilai kurang dan

\footnotetext{
${ }^{31}$ Muhammad al-Thahir ibn 'Ashur, Tafsi $\gg$ al-Tahłi $\gg$ wa al-Tanwi», 570.

${ }^{32}$ Abu Abdillah Muhammad ibn Ahmad al-Anshari al-Qurthubi, al-Jaði' li Ahła al-Qurað, 292.

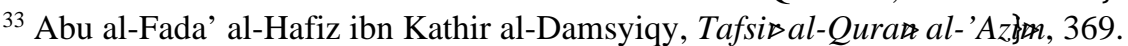

${ }^{34}$ Muhammad al-Thahir ibn 'Ashur, Tafsi $\gg$ al-Tahili $\gg$ wa al-Tanwi», 571.

35 Ibid., 573.

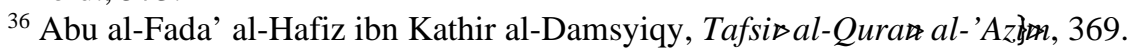

${ }^{37}$ Muhammad al-Thahir ibn 'Ashur, Tafsi $\gg$ al-Tahłi $\gg$ wa al-Tanwi», 571.

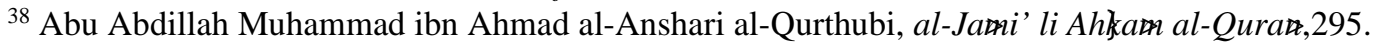

${ }^{39}$ Ibid., 296.

${ }^{40}$ Muhammad al-Thahir ibn 'Ashur, Tafsi»al-Tahłi wa al-Tanwi», 574.

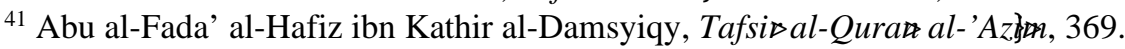


dimungkinkan lebih mudah lupa (dalam kesaksian) sehingga masing-msaing dari keduanya saling mengingatkan. ${ }^{42}$ Karena itu, kesaksian satu orang laki-laki dan dua orang perempuan setara dengan kesaksian dua orang laki-laki.

ayat ini menunjukkan bahwa para saksi di atas tidak boleh menolak jika dipanggil datang untuk memberikan kesaksiannya. Bahkan menurut Qatadah dan al-Rabi' ibn Anas, pemenuhan panggilan bagi para saksi untuk memberikan kesaksian adalah wajib. ${ }^{43}$ Sedangkan Mujahid menyerahkan sepenuhnya pemenuhan panggilan kepada para saksi itu sendiri. Jika para saksi itu mau memenuhi panggilan, maka dipersilahkan, dan jika menolak panggilan tersebut juga tidak apa-apa. Ibn 'Athiyah berpendapat bahwa pemenuhan panggilan tersebut adalah sunnah. ${ }^{44}$

ولا تسئموا أن تكتبوه صغيرا أو كبيرا إلى أجله dalam ayat ini Allah menyempurnakan penegasannya tentang perintah untuk melakukan pencatatan dalam setiap transaksi secara kredit, yaitu agar kita (para pelaku transaksi kredit) tidak bosan-bosan untuk mencatat ketentuan-ketentuan yang disepakati dalam transaksi kredit. Sebesar dan sekecil apapun ketentuan dalam transaksi yang disepakati diperintahkan untuk dicatat, ${ }^{45}$ karena dengan pencatatan tersebut hak dari masing-masing pelaku transaksi (kreditur dan debitur) lebih dapat dijaga, lebih dapat menolong untuk melaksanakan kesaksian dan lebih bisa meniadakan ذلكم أقسط عند الله و أقوم للشهدة و أدنى أل

ayat ini merupakan pengecualian (istithna $\Rightarrow$ dari penjelasan di atas, yaitu perintah melakukan pencatatan dan pensaksian dalam transaksi kredit. Di sini al-Shabuni menafsirkan dengan transaksi secara tunai (yadan bi yadin). ${ }^{47}$ Jika transaksi tersebut adalah tunai, maka tidak ada dosa jika tidak melakukan pencatatan atas transasksi tersebut. Menurut Ibn 'Ashur, tidak diperintahkan untuk melakukan pencatatan dalam transaksi secara tunai merupakan sebuah keringanan (rukhsłgh), namun jika pencatatan itu dilakukan, maka akan menjadi lebih baik (awla $>$ va ahłan). ${ }^{48}$

و أنشهوا إذا تبايعتم. Menurut Ibn 'Ashur, perintah pensaksian yang dimaksud dalam penggalan ayat ini adalah bersifat umum, yaitu perintah untuk membuat pensaksian dalam segala bentuk transaksi, baik itu secara tunai maupun kredit. ${ }^{49}$ Pemahaman serupa juga disampaikan oleh al-Shabuni. ${ }^{50}$ Adapun bentuk perintah dari و أثشهدوا diperselisihkan oleh para ulama. Abu Musa al-Asy'ari, Ibn Umar, Abu Sa'id al-Khudlri, Sa'id ibn al-Musayab, Mujahid, al-Dlahhak, 'Atha', Ibn Juraij, al-Nakha'i, Jabir ibn Zaid, Daud al-Dlahiri dan alThabari berpendapat bahwa bentuk perintah dari lafaz tersebut adalah wajib. ${ }^{51}$

و لا يضارّ كاتب ولا شهيد Ayat ini menjelaskan tentang hak utama bagi para saksi dan pencatat $(k a \dot{\vec{x}} b)$, yaitu tidak adanya madarat dari para pelaku transaksi terhadap mereka,

\footnotetext{
${ }^{42}$ Muhammad al-Thahir ibn 'Ashur, Tafsi»al-Tahłi»wa al-Tanwi», 574.

${ }^{43}$ Abu al-Fada' al-Hafiz ibn Kathir al-Damsyiqy, Tafsi $\gg$ al-Quraæal-'Az

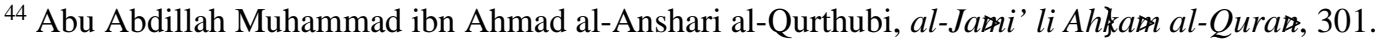

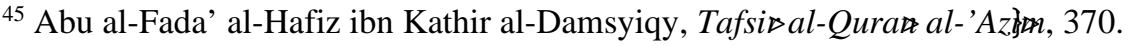

${ }^{46}$ Muhammad al-Thahir ibn 'Ashur, Tafsi $\gg$ al-Tahłi $\gg$ wa al-Tanwi», 579.

${ }^{47}$ Muhammad Ali al-Shabuni, Słfwah al-Tafasip, 178.

${ }^{48}$ Muhammad al-Thahir ibn 'Ashur, Tafsi $\gg$ al-Tahili wa al-Tanwi», 580.

${ }^{49}$ Ibid.

${ }^{50}$ Muhammad Ali al-Shabuni, Słfwah al-Tafasip, 178.

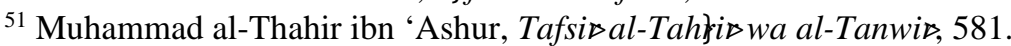


seperti menyudutkan mereka untuk menjawab pertanyaan-pertanyaan yang berhubungan dengan kesaksian, ${ }^{52}$ atau memaksa mereka untuk menunjukkan catatan dan memberikan kesaksian padahal mereka sedang memiliki kesibukan lain. ${ }^{53}$ Karena itu, bagi para pelaku transaksi yang memberikan madlarat kepada para saksi dan ka內ib, mereka dianggap sebagai orang yang maksiat kepada Allah, ${ }^{54}$ seperti yang ditunjukkan oleh ayat وإن تفعلو إفانه فسوق بكم.

و اتقوا الله ويعلمكم الله والله بكل شيئ عليم Surat al-Baqarah ayat 282 diakhiri dengan janji Allah, yaitu jika kita bertaqwa kepada-Nya, maka akan diberi ilmu oleh Allah, yaitu Allah memberikan cahaya (nu內) ke dalam hati orang yang bertaqwa sehingga ia bisa memahami apa yang disampaikan kepadanya.

Setelah Allah menjelaskan perintah untuk melakukan pencatatan dan pensaksian dalam transaksi seperti yang ditunjukkan oleh Q.S. al-Baqarah ayat 282, selanjutnya dalam Q.S. alBaqarah ayat 283 Allah menjelaskan tentang kondisi seseorang yang terhalang atau tidak bisa و و إن كنتم على سفر ولم تجدو ا كاتبا فرهن مقبوضة melakukan pencatatan karena adanya uzur, yaitu

Dalam ayat tersebut dijelaskan bahwa manakala seseorang bertransaksi secara kredit sedangkan mereka dalam kondisi musafir (bepergian) dan tidak dapat melakukan pencatatan karena tidak adanya ka ib untuk mencatat transaksi tersebut, maka disyariatkan bagi mereka untuk memakai sistem gadai (rahn) dengan marhuß (barang yang digadaikan) yang dapat dipegang dan diterima ( ) oleh kreditur (al-da in $).{ }^{55}$ Menurut Ibn Kathir dan al-Shabuni, tersebut merupakan ganti dari tidak dimungkinkannya melakukan pencatatan. ${ }^{56}$

فإن أمن بعضكم بعضا فليؤدّ الذي اؤنمن أمنته وليتق الله ربّه اله bahwa perintah pencatatan dan pensaksian dalam transaksi di atas boleh tidak dilakukan oleh para pelaku transaksi manakala telah terjalin sikap saling percaya di antara mereka ${ }^{57}$ dan adanya keyakinan bahwa di kemudian hari tidak akan muncul sengketa yang timbul dari transaksi tersebut. Berkenaan dengan perbedaan ulama mengenai hukum perintah melakukan pencatatan dan pensaksian, Ibn 'Ashur mengatakan bahwa penggalan ayat ini merupakan ungkapan penyempurnaan perintah pencatatan dan pensaksian dengan bentuk perintah yang berhukum sunnah, hukum yang dipegang oleh mayoritas ulama. ${ }^{58}$

merupakan larangan (al-nahy). ${ }^{59}$ Ayat ini melarang para saksi untuk menyembunyikan dan melewati batas dalam memberikan kesaksian, sehingga kesaksiannya itu sesuai dengan apa yang ia saksikan. Menurut Ibn Abbas, kesaksian palsu termasuk salah satu dosa besar, begitu pula menyembunyikan kesaksian. ${ }^{60}$ Karena itu, Allah melanjutkan firman-Nya dengan ومن يكتمها فإنه عاثم قلبه Pada akhir ayat Allah berfirman والله بما تعملون عليم, yaitu tidak ada segala sesuatu dari perbuatan dan perilaku manusia yang tidak diketahui oleh Allah.

\footnotetext{
52 Ibid.

${ }^{53}$ Abu Abdillah Muhammad ibn Ahmad al-Anshari al-Qurthubi, al-Jaðri’ li Ahła al-Qurað, 307.

54 Ibid.

${ }^{55}$ Muhammad al-Thahir ibn 'Ashur, Tafsi»al-Tahłi $\gg$ wa al-Tanwi», 584.

${ }^{56}$ Abu al-Fada' al-Hafiz ibn Kathir al-Damsyiqy, Tafsi $\gg$ al-Quraæal-'Az Shabuni, S\&fwah al-Tafasip, 179.

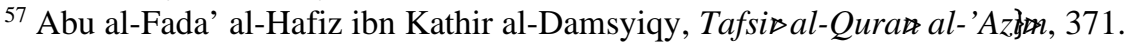

${ }^{58}$ Muhammad al-Thahir ibn 'Ashur, Tafsi $\gg$ al-Tahili wa al-Tanwi», 586.

${ }^{59}$ Ibid., 588.

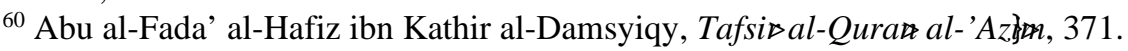




\section{Kesimpulan}

Dari penafsiran Q.S. al-Baqarah ayat 282 dan 283 di atas, maka berkenaan dengan transaksi secara kredit dapat disimpulkan sebagai berikut:

1. Bahwa transaksi secara kredit dalam Islam tidak diharamkan dan tidak makruh, dengan kata lain diperbolehkan meskipun harga barang yang diperjualbelikan secara kredit lebih mahal daripada harga secara tunai.

2. Dalam transaksi secara kredit diperintahkan untuk melakukan pencatatan dan pensaksian atas syarat-syarat dan ketentuan-ketentuan dalam transaksi tersebut. Tujuan dari pencatatan dan pensaksian ini adalah untuk menjaga hak dari masing-masing pelaku transaksi dan menghindari sengketa di kemudian hari. Dalam hal ini, para ulama berbeda pendapat mengenai bentuk perintah pencatatan dan pensaksian tersebut. Satu pihak berpendapat bahwa perintah tersebut adalah wajib, dan pihak lain berpendapat sunnah. Menurut hemat penulis, melihat tujuan dari pencatatan dan pensaksian transaksi di atas, maka pencatatan dan pensaksian dalam transaksi adalah wajib.

3. Adapun transaksi yang dilakukan secara tunai (yadan bi yadin), menurut penulis juga diwajibkan untuk melakukan pencatatan dan pensaksian. Hal ini merupakan bentuk kehati-hatian, karena pada saat ini banyak sengketa dalam transaksi yang muncul di masyarakat, padahal mereka sudah melakukan pencatatan dan pensaksian.

4. Nota perjanjian dan kwitansi yang disertakan dalam setiap transaksi pada saat sekarang memiliki arti penting untuk menjaga setiap hak dan kewajiban dari masing-masing pihak yang melakukan transaksi. Lebih-lebih, nota perjanjian dan kwitansi merupakan bukti yang sah dan konkrit yang menjelaskan kebenaran terjadinya transaksi.

\section{Daftar Rujukan}

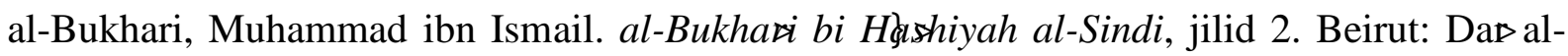
Fikr, 1995.

al-Maliki, Muhammad ibn 'Alawi. Zubdah al-Itqaæ fi>uluær al-Quraæ, cet. 3. Beirut: DaæalFikr, 1986.

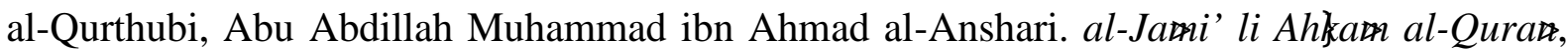
jilid 2, juz 3. Beirut: Daßal-Fikr, 1999.

al-Shabuni, Muhammad Ali. Słffwah al-Tafasi», jilid 1. t.tp., Daæal-Kutub al-Islaæriyyah, t.th.

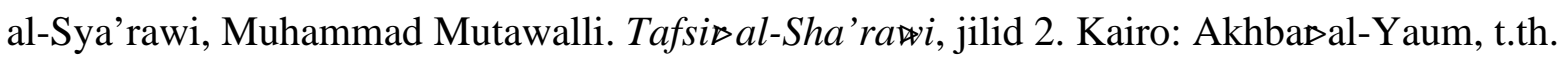

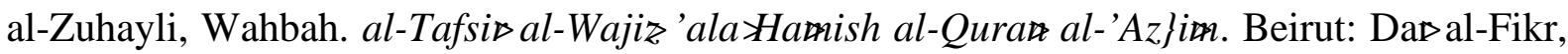
t.th.

al-Figh al-Islaær wa Adillatuh, vol. 5, cet. 4. Beirut: Da®al-Fikr, 1997.

Dahlan, Abdul Aziz [et al]. Ensiklopedi Hukum Islam, cet. V, jilid 3. Jakarta: Ichtiar Baru van Hoeve, 2001.

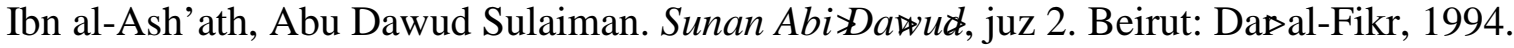

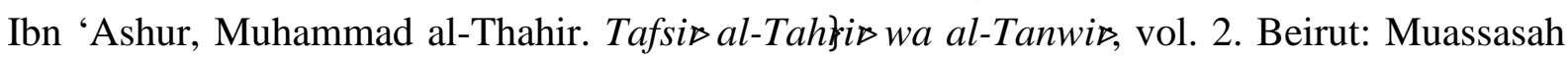
al-Tarimeh, 2000.

Ibn Kathir, Abu al-Fada' al-Hafiz al-Damsyiqy. Tafsi $\gg$ al-Quraß al-'Az al-Fikr, 1997. 